PEDRO OSÖRIO, SATURNO DAS GERAIS

Tieko Yamaguehi Miyazaki

Julieta Haidar de Marinez̃ 

Tieko Yamaguehi Miyazaki Julieta Haidar de Mariñez

1.0. Este trabalho é, na verdade, a continuação e conclusão d dois. artigos: o primeiro - "0 recado do morro" -, publicado em Signi$\underline{\underline{\underline{\text { ica }} \mathbf{c} a O}}, \quad 2,1975$ e o segundo - "os recados do morro" - publicado en Mime sis, 2 , 1976 . No primeiro artigo procedemos a uma ánalise da fábu la amorosa e da traição e da fábula do passeio da comitiva guiada por Pedro Orósio pelos chapadões mineiros. Através de uma focali-zação fun cional à luz da morfologia propp-greimasiana da narrativa tentamos es tudar a inver s̃ão sofrida na distribuição dos atores pedro orósio e Ivo na categoria actancial herói/vilão (ou sujeito e anti-sujeito), para chegar ã apreensão de uma nova fábula, a fábula da transmissão ao sujeito do conhecimento de seu próprio destino. É nesta que o recado do morro - fato estranho e inusitado - parece encontrar a sua signifi cação. o segundo artigo foi dedicado ao estudo das transformações so fridas pelo recado transmitido pelo morro a pedro orósio. o trajeto destinador-destinatãri o da mensagem que dá o titulo à obra^^^pode ser visto como um tortuoso trabalho de abertura do canal de comunicação. De função antes de mais nada fática, o percurso realizado pela mensa gem é uma longa distância que, por longa e acidentada, acarreta a transformação da mensagem original em uma nova mensagem. Tal transfor mação, devida ãs dificuldades apontadas, ñao é gratuita; pelo contrá rio, ela propoe uma nova leitura do "caso extraordinariamente comum" acontecido com o enxadeiro Pedro Orósio, na qual este se revela um he rói mítico. Para uma configuração global de orósio como herói mítico faz-se necessária, entretanto, uma análise do Destinador, primeiro, do recado original e, depois, do recado transformado. Para isso, vamos Partir, neste novo artigo, do texto final da mensagem - a canção de Laudelim - para chegarmos à estória contada pela narráçao, pelo dis curso verbal do narrador. 
ças jã apontadas nos artigos acima citados, entre a canção de Laud£ lim e as ver $\tilde{s} \tilde{e} e s$ do recado dos demais receptores outras hã que pare cem explicar por que só com o cantor-poeta ocorre a decodificaçao do recado por Pedro orósio.

Na medida em que a mensagem do morro se vale de uma língua natu ral, ela se transforma, antes de mais nada, em uma mensagem linguístíca. Isto implica, automaticamente, a presença, de unidades de signifî́ cantes e de significados que os signos lingüisticos enquanto tais a carretam. Todos os atores diretamente implicados - com exceção de seo Alquiste - decodificam numa primeira, instância a mensagem linguíștî ca, facultada pela sua competência da língua portuguesa. o plano do significado, entretanto, os remete a um sistema simbólico claro: o b_í blico. Isso se mantém na versão do recado de todos os seis primeiros receptores. Em contraposição, a canção de Laudelim, embora usando mais ou menos os mesmos sintagmas lingüísticos, tornados fixos, lib£ ra o canto dessa referência direta ao universo bíblico. Ele respeita tais referências, mas com elas cria um mundo medieval - cavalheiresco cujo carãter ficcional não escapa ao auditório. As versões dos demais receptores exigem do. destinatário a crença na possibilidade de que os fatos referidos venham a ocorrer no mundo fenomenal. Entretanto, mundo a que remete o significado bíblico dos signos lingüisticos é re legado por todos a um mundo mítico, localizado num tempo remoto, que se que sem nenhuma ligaçao com o seu. Pois a sociedade representada no texto, caracteriza-se como uma sociedade desmitificada em tal grau que qualquer manifestaçao de forças nao naturais ésta descartada a priori.

Embora o momento da açao focalizada seja justamente um momento de concentração mítico-religiosa, o sentimento da coletividade é aci ma de tudo profano. A figura do padre que integra a comitiva encarna essa dualidade: apesar da constância de seu pensamento voltado para o ultraterreno - daí a insistente observação do narrador quanto à leitu ra do breviário - ele se iguala aos leigos quanto ao recado do morro. A distribuição dos atores em receptores e não-receptores do recado se fundamenta, portanto, na oposição crença e ̃̃ao crença na veracidade da mensagem.

A canção de Laudelim, pelo contrário, dispensa o texto dessa re ferene ia lidade direta e obriga o destinatário a concentrar-se nele, 
texto. Cria uma verdade própria que desobriga o ouvinte de uma prova de veracidade. Apesar do ambiente medieval dos acontecimentos relata dos, em que se aproveitam, preservando-as, as referências bỉblicas, a mensagem torna-se a-temporal e a-espacial e não se destina a um destî natãío específico. Por isso, embora seja a canção a transformar pe dro orosio de receptor - e mau receptor - em destinatário, fazendo com que o recado original seja recebido (a morte dele ã traição), a sua significação não se esgota nisso. Dessa perispectiva o canto'se ré duziria - como aliás a atuaçao dos demais receptorés - a instrumento de um recado ñao mais "extraordinariamente comum" mas simplesmente comum.

2.1. Tal diferença pode ser mais bem explicada pela conceitui ção de Lotman e pjatigorky de cultura, texto e função. Para eles, "na noção cultural de texto toma-se como ponto de partida o momento em que a express.ä́o simplesmente lingüística deïxa de ser percebida como suficiente para que uma mensagem se torne texto". Para que uma mensa gem se torne texto, ã necessário que "apresente índices de uma expres são suplementar, significante no sistema da cultura dada") . A fun ção do texto se define pelo papel.social que este desempenha, pela af tidão de responder a certas necessidades da comunidade que cria o tex to. A cultura seria então ou o conjunto de textos ou um conjunto de funçõ̃es.

A partir dessa visão, as sociedades podem ser classificadas em: de cultura de tipo fechado, vista como a continuação, segundo a tradição, de um tempo em que existia a "plenitude da unidade";

de cultura de tipo aberto, aquela em que se acumulam progressivamente os elementos da verdade cuja plenitude é vista só no futuro.

E de acordo com a forma de organização dos textos as sociedades se classificam em:

de estrutura paradigmática,

de estrutura sintagmática.

Tem-se uma comunidade de estrutura complexa quando se verifica a coexistência de uma estrutura paradigmática e uma estrutura sintagmática, na qual esta vai preponderando progressivamente. Isto ê, uma cultura de tipo fechado vai sendo substituída por uma de tipo aberto. Nela persiste a função do "texto pleno", mas vigora também uma visão histórica que promove a perda progressiva dessa plenitude. 
Parece ser este o caso da sociedade focalizada pela nossa narra tiva: embora leia constantemente o texto sagrado, o texto da plenitude, frei sinfrão é incapaz de aceitar a mensagem do morro como um tex to de função transcendental. Como o destinatário de um texto pleno se interessa não só pela veracidade da informação mas também pela informação em si, ao lado do texto aparece necessariamente a figura do seu intérprete. Este deve ser dotado de tais atributos que se exclui a possibilidade de qualquer um vir a sê-lo. No texto rosiano, tanto oró sio quanto os demais atores ñao reconhecem nos'receptores do recado essa condição de eleitos: para pedro orósio, estes seriam pessoas in^ truídas e não simples anormais.

Por outro lado, o texto da mensagem retransmitida abunda em v e feréncias bíblicas. A visão sintagmática, histérica, porém, ao trazer como conseqüência a debilitação da função social do texto bíblico, pro voca um sentimento de desconfiança com relação do texto do recado: os índices ev id en $t$ e $s$ de que se trata de uma mensagem decalcada no textc bíblico, tornam-se índices de sua própria falsidade. Pois, conforme ex plicam Lotman e pjatigorky, "de caution de vérité, des índices des tex tes deviennent les témoins de sa fausseté. Dans ces conditions, on se trouve devant une relation secondaire inverse: pour qu'une communication soit perçu comme vraie et valable (c'est-á-dire comme texte) elle ne doit comporter les índices apparents de texte. Seúl un non-tex te peut, dans ce cas, remplir la fonction de texte".

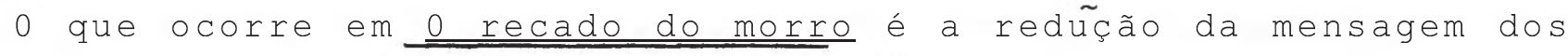
seis primeiros receptores a uma comunicação lingüistica simplesmente, devida ã transformação dos índices de verdade em índices de falsida de. Ou em índices de insanidade. A sua substituĩção pela canção de Laudelim mostra que a mesma função social é desempenhada por outro ti po de texto. Neutralizados os indícios propriamente bíblicos, o novo texto cria índices próprios que o identificam como texto. Um deles es tá na própria escolha do mensageiro: o poeta-cantor, uma classe de pessoa de atributos específicos, portanto. Outro é a própria litera riedade da canção, isto é, as características que a identificam como texto poético.

Ao fazer-nos perguntar pela sua funçao, o longo caminho da trans missäo do recado assim retraçado, coloca, conseqüentemente, a própria significação do recado no contexto da narrativa a qual está na depen dência da identificação do Destinador. E para isso é preciso voltar 
3.0. 0 Destinador: . A qualificação heŕoica de Pedro Orósio, vista em uma análise da narrativa nos moldes propostos por propp eGreimas, i confirmada pela atribuição ao ator da função de destinatário deuma mensagem $\underline{\underline{\text { inusitada }}}$. Enquanto. estória extra-ordinária, a estória de Pe dro Orósio só pode ser entendida atrāés do que se considera ordinã rio. Isto é, o fato extraordinário se reduz àinsignificância na med_í da em que é considerada como tal simplesmente. É preciso levar em con ta a sua relação lógica com o ordinário, ponto de referencia implíci to na própria classificaçao do fato como extra-ordinário. Na narrativa, dá-se não uma relação de exclusãó mas de inclusão do extra-ordi nãrio no ordinário. Assim, dentro do mundo ordinário torna-se verdade, para o leitor e para alguns atores, que o morrofale.

Desde o início, o actante Destinador se manifesta asim nafor ma do ator morro da Garca (4). Sabe-se, por outro lado, que apesar da autonomia e dignidade que o narrador confere a esse acidente geogrãfi co, a afirmação de que se trata, antes de mais nada, de um acidente geográfico, pertence ã própria narrativa. Desta forma, admitir que o morro fale corresponde a reconhecer nele o ator através do qual o ver dadeiro Destinador se manifesta. A identificação do Destinador, na me dida em que este se apresenta hipotaticamente através de subsitutos do morro - os receptores humanos da mensagem - nos obriga a percorrer - caminho dos significantes descontínuos que se encontram espalhados pelos enunciados e pela enunciação, do texto.

3.1. A primeira identificação desses significantes se apresenta na relação entre a categoria actancial e a categoria dos atores. Isto é, apreender a base isotópica dos atores para se chegar a uma relaça semântica necessária entre cada um deles e a categoria actancial que realizam. Em outras palavras: em nossa narrativa, parece-nos viável pensar que características do Destinador se manifestam nas caracterís ticas dos atores que o manifestam. Em se tratando do actante mais im portante da categoria - afinal é ele que encarna o sistema semânticoideológico que põe a narrativa em movimento - o Destinador ña se ma nifestaria obliquamente na escolha de coadjuvantes, heróis e oponen tes?

Partindo dessas premissas, podemos considerar no ator morro as $-19-$ 
seguintes, características:

elemento natural inanimado, geológico, marcado por uma orientaçã̃o vertical superativa.

Levando-se em conta a orienta çao vertical superativk, pode-se qualificar o morro como a man ifestaçao, correspondente nas regiões af reas superiores, das profundezas terrestres - das lapas e grutas em que abunda a regiãa. Por isso o morro e a gruta de Maquiné se equip^ ram quanto ao papel actancial que desempenham na narrativa. Se é o morro que transmite o recado de Malaquias, é na gruta - lugar de som bra e a têmpora 1 idade - que Pedro Orósiofica sabendo de coisas que "nunca soube". Morro e gruta sao dois acidentes geográficos que se c£ locam em uma relação de oposição radical quantoao eixo da verticalidade no qual ocupam posiçoes $\underline{\underline{\text { marcadas }}}$. Entre eles se interpõem os ef paços do horizonte em que se movem os humanos. Entende-se graças a es_ sa distribuiçã̃o espacial por que, para fazer veicular a sua mensagem, - morro necessita de atores humanos que sirvam de mediadores ente ele e o seu destinatário: este se situa no espaço intermediário, que pode mos qualificar de ordinário e, portanto, não marcado.

o primeiro dos receptores é também o mais importante, pois dele depende que o recado comece ou ña a sertransmitido. Como mediador que aproxima dois termos polares - Orósio e o morro, ou seja o humano e não humano - deve Malaquias justificar a sua função de termo comple $\mathrm{xO}:$

MORRO

n

a

t

r
MALAQUIAS

Ser humano, cujo comportamen to oscila do pólo da nã̃-sociabilidade ao da extrema po스lidez, denunciada pela sua postura e fala.

A sua nã-sociabilidade en contra correlaçã em seu nã̃ distanciamento da natureza:e le vive ainda nas entranhas destajem oposição aos seres "normais" vive em um dos es paços marcados de nosso es quema .

\section{PEDRO ORÓSIO}

Ser humano em que a cultura se apresenta na forma de um com portamento social cuidado e no uso de um sistema lingüístiC $\circ$.

A natureza está nele presente na forma de sua incapacidade de pensar discursivamente, uma propensão ã letargia mental e pela profissão: agri cu $110 r^{\wedge} \wedge$. Esta se encontra porém, já me diatizada pela cultura. 
A mediatização de Malaquias, entretanto, se revela insuficiente para transpor a distäncia interposta pela cultura entre Destinador e Destinatário. A necessidade de novos mediadores no início quase se di vide em duas alternativas: de um lado, Alquiste e, de outro, os seis demais receptores. Como jã assinalamos, ocorre no encontro do grupo com Malaquias um momento que a comunica ção entre este e o alémao se apresenta totalmente propiciada quanto ao contato, ao canal. o código lingüístico comum inexistente entre ambos parece ser suprido, como o correra com o morro, por um código pri-1ingüístico, contíguo i Nature za. No alienígena, manifesta-se ainda a Natureza na inôcencia deseo berta em seus olhos ("tirados os óculos, de grandes grossas lentes, seus olhos se amaciavam num aguado azul, inocente e terno") urna vez removida a mediatização da civilização (os óculos). A inoceñcia e-̃o eixo conjuntivo entre ele e os receptores subsequentes: Catraz, Guegue e Jãozezim. Se em Catraz a Natureza está presente na forma de sua pro ximidade física à térra (vive, como o irmão, em urna lapinha), só se pode compreender a escolha de um idiota e uma criança parareceptores se se considera a inôcencia como um estado denão-cultura, isto é, co mo marca do paradigma Natureza.

0 motivo da inocência em Alquiste confirma a presença de um no vo elemento que caracteriza todos os receptores seguintes: a coexistência neles de dois mundos contiguos - sagrado e profano - que se in terrelacionam e interagem. Se bem que nem sempre os próprios sujeitos saibam onde se situam exatamente as fronteiras entre eles. Em Mala quias essa crençase reveste de um certo primitivismo e emcatraz, Gue gue e Jãozezim seatenua em inoceñcia.

A insuficiência dos tres receptores que seguem a Malaquias se explica pelas gradações que levan a um novo termo complexo:Nominedómi ne. A distancia que se interp̃oe entre Malaquias e Nominedómine pode ser aquilatada pela diferença entre os intermediários que lhes cabem: enquanto o primeiro o identifica em um acidente geológico, o segundo - reconhece em um ser supra-humano: Guegue visto como um anjo. o cará ter sacro da sociedade focalizada parece, porém, persistir em sua opo sição ao caráter religioso da pregaçao de Noninedomine. Por isso, no receptor seguinte, o coletor, a coexistência dos dois mundos tem moti vação e forma de manifestação profanas.

Mas pelas razões que apontamos no início deste trabalho, o ter mo complexo que se torna capaz de desempenhar cabalmente a sua funça 
é aquele quem que o outro mundo se apresenta na forma de ficção lite rãria. Opondo a sua natureza transcendental ã natureza transcendente da visão bíblica das mensagens anteriores, o texto poético continua portanto a afirmar a coexistência de dois mundos e de sua interação.

Nessa seqüência de termos complexos, tem-se assim uma dosagem cada vez maior de elementos culturais através dos quais a distância entre o morro ou a Natureza e Pedro orósio vai sendo vencida.

3.2. A permanência da Natureza na Cultura parece ser, portanto, um dos pontos-chaves do relato. A sua manifestaçao se faz de forma a acarretar ou não choques com os sistemas sociais vigentes na comunida de. Isso pode ser verificado no relacionamento afetivo dos atores.

Os atores masculinos e femininos, dividem-se respectivamente em elemento ativo e ñao-ativo no relacionamento amoroso. A correspondên cia das categorias femini 1 idade/masculinidade e ativo/nao ativo é s $^{\wedge}$

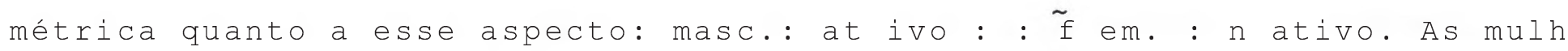
assim caracterizadas, apresentam sempre o mesmo tipo de comportamento afetivo com relaçao a orósio: uma reläçao eufórica ou em termos de simpatia simplesmente ou em termos de pretensas namoradas. Ou seja, tanto as mulheres passíveis quanto as não passíveis de um relacionamento amoroso com Pedro Orósio, o vêem com bons olhos. Não é isso que acontece com a comunidade masculina. Esta se divide claramente em dois grupos: os de relacionamento eufórico e os de relacionamento dis fórico. Entre os do primeiro grupo colocam-se os atores que, por ra zões diferentes, não se situam numa posição de rivalidade amorosa com Pedro Orósio: pelo contrário, quase se identificam com ele (Frei Sin frão, seo Alquiste...). Ao segundo grupo pertencem os rapazes por ele prejudicados em suas empresas amorosas.

Com exceção, portanto, dos atores que se enquadram no segundo grupo masculino, a simpatia gratuita por pedro orósio parece ser do consenso geral: "E, apesar d'ele ser capiau, roceiro muito, as pes soas finas apreciavam o pedro principalmente por seu tamanho em desa buso, forçudo assim, dava gosto a respeito". o herói aparece assim do tado de atributos apreciáveis pelo ser humano sem distinção de sexo ou classe social.

3.3. A raz̃ao de tal simpatia geral parece dever-se-a oposição: situar-se a si e aos objetos desejados no eixo das não-injunções do 
hexágono lógico. Para Pedro Orósio vigora sempre o eixo das não-pres crições e das não-proibições, o que lhe proporciona uma visão da vida sem complicações: "Todos os companheiros estavam de volta com ele e lhe franziam cara por meia bobagem de ciúmes. (......... Toda desaven ça desmanchava o agradável sossego simples das coisas"(p.10).E a fruî ção ingênua das forças físicas enquanto tais:"Capaz de cravar de en golpe em qualquer terreno uma acha de aroeira, de estalar em quatro em cruz os ossos da cabeça de uma marruás, com um soco em sua cabeloura, e de levantar do chão um jumento arreado, carregando-o nos braços por meio quilómetro, esquivando-se de coices e mordidas, e sem por isso a frouxar o fôlego de ar que Deus empresta a todos"(p.5). As sim caracte rizado, Pedro orósio se apresenta como o termo marcado da estrutura:

$\underline{\underline{\text { Pedro Orósio }}}$

(Manifestação "desabusada"

da Natureza)
$\mathrm{V} \mathrm{S}$

demais atores masculinos

da Natureza)

Não ê propriamente a beleza física do ator que o torna atraente, mas - seu tamanho fora do Comum, sua força fora do normal. o termo "desa busado" i do próprio texto e traduz bem o motivo da admiração da comu nidade. Desta forma, partindo-se de que tamanho e força em desabuso gosto e respeito, tem-se que tamanho e força normais não-gosto e não-respeito, donde se pode concluir que o termo positivamente marca do da oposiçã̃o categórica euforia/disforia é o que situa o ator fora das tegras, no eixo das não-injunções.

Mas a ausência de injunçoes - positivas ou negativas - requeri da pelo sistema de valores de personalidade dos atores masculinos do segundo grupo, na prática acaba transformando-se em prescrições e proibições:

"Cada qual queria ser sem chefe, sem obriga çao de respeito, al forriados de qualquer regra" (Rosa, 1969, p. 43).

Como á justamente o exercício das prescriç̃ões expressas na citação a cima que vai provocar a divis̃ão dos atores masculinos nos grupos há pouco apontados, fica denunciada aí a contradição dos dois sistemas. o jogo das injunçoes convencionais para o relacionamento amoroso, em que ê injunção proibitiva a relaçao dois sujeitos masculinos para o mesmo objeto feminino, choca-se com a total liberdade de ação deseja da. 
A fựção de Pedro Orósio é, portanto, de apontar essa contradî ção e i por esta raz̃ao que, como tentamos demonstrar na ánalise das funções narrativas, di-se a inversão entre Ivo e Pedro oŕosio quanto âs categorias actanciais herói/virão. Isto é, Pedro órosio de vilão passa a herói e Ivo de herói-vítima a vilão. Através de tal inversão, os valores considerados positivos dentro dos sistemas sociais passam, portanto, a negativos. Mas para que essa inversão se realize efetivamente, é necessário que â "naturalidade" de Pedro orósio se alie a Cultura. A predestinação do herói a uma missão superior finaliza pelo acréscimo do saber e do $\underline{\text { querer }}$ ao $\underline{\text { poder }}$ conferido pela Natureza. Até então a Cultura se apresenta na narrativa, em sua forma radical de m£ nifestação (ciêne ia), principalmente na figura de Alquiste. A relação paradigmática entre este ator que acompanha o grupo (e é a raz̃ao de le) do início ao fim (o frei e seu Jujuca o abandonam quase no fim do trajeto) e Pedro orósio é confirmada pela transformãçao de um exclama ção daquele ("Skol") em brado de guerra deste ("Escola"), justamente no momento correspondente ã prova de glorificação do herói: a luta contra os sete traidores.

Pedro orósionão é, portanto, a manifestação da natureza sim plesmente na estrutura mínima: Natureza vs. Cultura. Da mesma forma não caberia identificar o Destinador da mensagem e do destino de oró sio com a Natureza. A identidade dele permanece oculta, mas sugerida através de uma vĩ̃a ñao mais profana da realidade cotidiana mas de uma visáo do mundo como um lugar onde cabem ainda grandes destinos. A única explicação que nos parece caber a esse anonimato do Des tinador mantido durante a narrativa toda é a que dá Greimas:

"trata-se de um caso de alexica lidade da estrutura do Destina dor, istoé, a impossibilidade em que se encontra uma comunidade his toricamente definida de manifestá-la no discurso."

4.0. A mensagem narrador-leitor. Ao falarmos em decodificaçã limitamo-nos até aqui quase que exclusivamente ã codificação e decodi ficação da mensagem pertencente -a fábula da narrativa. Deixamos, as sim, de lado a mensagem global que nos coloca na posição de destinatários e conseqüentemente de decodificadores. Isto é, há no texto um narrador que se vai configurando através de marcas deixadas erratica mente ao longo de seu discurso, de seu ato de narrar. A mensagem por 
ele construída não se limita â narração de "um caso de vida e morte, extraordinariamente comum que se armou com o enxadeiro Pedro Orósio". o seu discurso ganha autonomia e se transforma de expressão verbal de uma história em uma nova mensagem dirigida ao leitor.

4.1. A decodíficaçao do recado do morro ê proposta em dois veis. Uma ao nível dos atores, enquanto seres reunidos em um espaço e um tempo em que atuam; outra, ao nível do leitor. Isto significa que a decodificação do recado pelo leitor, por situar-se nesse nível, áe. veria ocorrer antes de sua decodificaçao pelo herói. Mas isso ñao se verifica, pois numa primeira leitura do texto o leitor não se antecipa ao herói, deixando-se guiar docilmente pelo narrador ati o clímax da ação.

Esta não antecipação do leitor a Orósio ê um testemunho da com plexidade do texto rosiano. Isto porque, embora ña no mesmo estilo de Borges, o narrador possui uma grande maestria em povoar o caminho do leitor de sinais e índices sem que contudo este se dê conta deles. Só numa releitura, jã de posse da chave da charada, ê que o leitor se dá conta do fato.

Esta vantagem que o leitor leva sobre o herói se deve á sua pró pria condição de leitor. Leitor pressup̃õe mensagem organizada com a intenção de comunicar; ei-lo, pois, ante uma mensagem apresentada desde o início como significante, isto i, significando. A mensagem lingüistica, assim encarada, implica uma representação_analítica da experiência a ser contada, imposta pela linearidade do discurso que seleciona, concomitantemente, falas, açoes, seres, espaço, tempo. Im plica, ainda, a necessidade de nomear esses mesmos fatos, seres e ações, tempos e espaços, o que acarreta ñá só a escolha de articula ções sêmicas ao nível denotativo, mas ainda a escolha de perspectivas cognitivas, ideológicas de entendimento.

A mensagem assim vista - como uma ordenação intencional, significante - opõe-se verticalmente ao mundo em que se move o destinatã rio do recado do morro. Este ê nao só destinatário de uma mensagem verbal mas de uma mensagem construída de signos instituídos ao nível do próprio mundo extensional. 0 que quer dizer que, para cumprir ca balmente a sua função de destinatário, o herói deve saber transformar - mundo, de simples conjunto mais ou menos cático de referentes, em um grande e complexo sistema semiótico. 
0 ator lida com o mundo extensional em dois nĩveis: primeiro, como um acervo de coisas, objetos, cuja vísao está determinada pela interação de várias perspectivas ideológicas; e, segundo, como um a cervo de coisas, objetos em função signo (o sapato pode significar calçado mas também situação económica), aos quais se misturam objetos que não desempenham essa funçao. No mundo extensional cotidiano, os objetos em função-signo não compõom por si śo uma mensagem. A inteil ção significante é acrescentada pelo sujeito aos objetos. só entaó es_ tes passam a articular-se segundo estruturas sintático-semanticas prón prias de cada sistema. 0 sujeito, portanto, é obrigado antes de mais nada a fazer um trabalho de identificação de unidades significativas, separando-as das não significativas, em conformidade com as pertinên cias ditadas pelo sistema adotado.

Esta diferenciação das condições em que se encontram o leitor e Pedro Orósio como destinatário de um mesmo recado, parece-nos fundeí mental. A observação da própria personagem: "os que sabem ler e escre ver, a modo que mesmo o trivial da idéia deve ser muito diferente...',' embora referindo em primeiro lugar os atores da própria estória, f<D caliza o mesmo problema.

o nümero de signos com que o herói trabalha i inferior ao do codigo do leitor. Para ele o nome dos donos das fazendas e a caracterização geográfica destas por exemplo ña participam da mensagem a ser decodificada. A mensagem do morro, enquanto enunciado e enunciação, faz parte, porēm, do enunciado da mensagem narrador-1eitor . Há signos de conteúdo simbólico da segunda mensagem que só o sao graças â rela ção de necessidade que a condição de mensagem intencional institui en tre signo e referente, em oposição à relaçao de arbitrariedade que o rienta a visão do herói, como veremos adiante.

4.2. Toda a magistral inťrodução da narrativa está povoada $d \epsilon$ índices propostos ao leitor:

"Sem que bem se saiba, conseguiu-se rastrear pelo avesso um caso de vida e morte, extraordinariamente comum, que se armou com o enxa deiro Pedro Orósio (também acudindo por Pedrão Chabergo ou pê-Boi, de alcunha), e teve aparente princípio e fim num julho-agosto , nos fun dos do município onde residia, em sua raia noroestã, para dizer com rigor" (p.5).

A forma apassivadora usada nas duas primeiras frases - "bem se 
saiba", "conseguiu-se" - antes de mais nada tem a seguinte função: não deixar que seja identificado o sujeito semântico da açao e com isso encobrir-se a forma como o caso veio ao conhecimento público. Apesar disso, a excepcional idade do caso est́a expressa ñao só pelo verbo mo dalizante conseguir, como também pelo verbo $\underline{\underline{\text { castrear }}}$, em que está im plícito todo o trabalho semiõtico do sujeito: a interpretação de sî́ nais. Está expressa também no sintagma de funçao modal - "pelo aves so" - que nos prop̃oe a oposição de perspectiva - anverso e reverso das coisas - e conseguinte a pergunta: a narração se fará pelo avesso ou pelo direito? Embora â primeira vista a declaração "um caso de vî́ da e morte" pareça propor sem erro o núcleo da intriga, ela encerra, no entanto, uma forte ambigüidade graças ao seu forte teor generali zante. Esta ambigüidade é confirmada logo depois no ousado oxímoro: "extraordinariamente comum".

A posição do ator central se reduz a destinatário de uma açao cujo sujeito semântico novamente se camufla ao nível do discurso 1 in güístico, sob a forma apassivadora: "armou-se com o enxadeiro". os in formantes - na terminologia de R. Barthes - também perdem a sua nit^ dez referencial: "teve aparente princípio e fim", e obrigam a fazer a oposição aparente/real princípio e fim. Estes sao alguns dos elemen tos com que o narrador situa o seu receptor e lhe configura o instan te mesmo de enunciação e recepção da narrativa. Eis, pois, o leitor nu ma situação de comunicac̃̃ä verbal, em que fatos dele desconhecidos e de limites pouco claros lhe são apresentados.

A sua consciência, desta forma despertada e moldada, ê assim mantida no trecho seguinte, o da apresentaçao dos atores. Sendo esta a função do texto nesta parte da narração, destaca-se na enunciação o eixo emissor-receptor e a liberdade do primeiro de selecionar e de or denar os elementos que devem compor a sua mensagem verbal. $\tilde{A}$ vista dessa situação de liberdade seletiva por parte do emissor, é facilmen te perceptível a diferença de tratamento dado aos atores, uma diferen ça qualitativa (quanto ã perspectiva eufórica ou disfórica) e quanti. tativa (quanto ao maior ou menor número de palavras dedicadas a cada um deles).

A ordem de apresentação dos atores é duplamente pertinente: is__ toé, não obedece só ã distribuição dos membros do grupo, mas homolo ga a hierarquia qualitativa deles e os paṕeis temáticos e actanciais que vão desempenhar: Pedro Orósio, Alquiste, Frei sinfraõ, Jujuca e 
IVO.

A caracterização dos atores se faz basicamente quanto aiaspecto fủsico e indument́aria, procedencia e nome. A distribuição da catego ria euforia/disfor ia depenie, ás vezes, do ângulo de enfoque das coi_= sas: a apreciação é feita i partir de urna ví̃ao locai, e da classe so_ ciai a que pertence orósio.

4.3. Desde o começo, portanto, já ao nível da narração e não do relato, Orósio é apresentado como herói, como o termo marcado da narrativa. Em contraposição, a esta postura inicial do narrador - o qual deixa bem clara a sua condição de narrador, através da preponderância do discurso sobre a história -, no desenrolar da narraçao, aos olhos do leitor o relato vai sobrepujando progressivamente ao discurso. le to graças ao uso freqüentedo discurso indireto livre quejoga lei, tor no centro do relato, fazendo-o aproximar-se dos, fatos contados e distanciar-se do dicurso que decodifica. $:$

Conseqüência indireta desta nova situação do receptor é uma fra ca apreensão dos signos aonível do discurso: em oposição ao trecho introdutório da narrativa, o discurso ganha transparência aos olhos do leitor, em detrimento da opacidade inicial.

Isso explica em parte por que o leitor ñao se antecipa ao herói na decodificação do recado do morro.

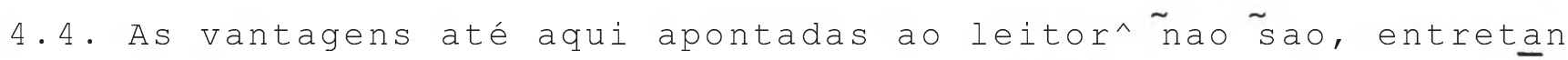
to, suficientes para garantir-lhe uma decodificação ideológica da men sagem. Esta requer um saber específico do destinatário, como passamos a ver.

o nümero sete aparece insistentemente no texto: não só ao nível do relato (sete mensageiros, sete traidores, sétimo dia de penitência de Nominedómine, a gruta de Maquiné "com os seus sete salões encober tos", uma moça civilizada "com um colar de sete voltas", folha "sete -sangr ias"), como também ao nível do discurso (Pedro orósio era um se te-pernas", Nominedómine de "sete fôlegos"). Segundo Ludwig Paneth, o número sete, como todos os ñumeros primos, é um dado irredutível, a expressão de um conflito, de uma unidade complexa; significa ordem completa, ciclo, período; está composta da união do ternàrio e do qua ternàrio, daí o valor excepcional que se lhe atribui. De todas essas significações, é possível destacar um denominador comum: uma unidade 
complexa, irredutível. Denominador comum que se pode identificar não só na própria significação da estória de Orósio e nos elementos de que esta se compõe, mas ainda no carãter mítico que o relato ganha, e no próprio texto como texto literário.

4.5. A simbologia crista também i um conhecimento que se exi do leitor. Ela se manifesta em vários pontos da narrativa. De início, Malaquias: o nome do primeiro mensageiro remete-nos ao Velho Testamen to e estabelece, assim, a isotopia inicial do recado do morro; logo após, Catraz que se transforma, ao longo da transmissão do recado, em Ca if az, cuja popularizãçao explica por que ê este o nome que promove a decodificação final da mensagem. ̃̃ isotopia anterior acrescenta-se a disforia da traição. Esta disforia é traduzida logo mais quando o plano da viagem é desobedecido pela inserção de um passeio não progra mado: "De vez, ora assim foi que, no outro dia, em vez de torarem pa ra o arraial, ainda $\underline{\underline{\text { inv ent ar }} \text { am de enrolar caminho para as Traíra } s}$ - (g: fo nosso, p. 40).

Vê-se, por aqui, que nomes atribuídos a atores humanos e a aci dentes geográficos, dão exemplos de signos que, pela perspectiva do relato, mantêm com o seu referente uma relação de aparente arbitrarie dade: enquanto que ao leitor torna-se clara a relaçã de necessidade entre eles: por que o grupo vai dar em um local chamado exatamente "Traíras"? Dentro dessa perspectiva, ao ser usado para nomear determi nado referente do mundo extensional, o signo em sua unidade de signi ficante e significado seleciona de anteñao as fuñ̄ões que aquele de sempenharã. o nome Malaquias antecipa a função do ator.

Essa mesma diferença de enfoque se apresenta com relação aos no mes dos fazendeiros, por cujas propriedade passa grupo (Apolinãrio, Marciano, Nha Selena, Nhô Hermes, dona Vininha, Jove); e dos traido res (Hêlio Dias Nemes, Martinho, João Lualino, Zé Azouge, Veneriano, Jovelino, Ivo Crônhicol. De imediato observa-se a correspondência ter mo a termo dos dois conjuntos, faltando, pórem, o que deveria fazer par, no paradigma dos fazendeiros, com Ivo. Essa lacuna e a própria correspondência dos dois conjuntos que se encontram na mesma referên cia - os planetas ou os deuses -, constituem a chave da mensagem nar rador-leitor. Mas essa chave está camuflada ao nível do discurso: o narrador se vale de diferentes expedientes que despistam o leitor, fa zendo-o ater-se ao relato. 
No trecho em que se narra o término da viagem, vãrios sãos os Indices que o discurso apresenta ao leitor de que ele se refere à vol. ta. Os três primeiros parágrafos introduzem a transição das duas se qú ênc ia s:

1. "Adiante houve dias e dias, dado resumo".

2. "Aonde queriam chegar, até lã chegaram, a comitiva,em fins".

3. "Mas, quando vinham vindo, terminaram o torna viajem, já..."

Em todos eles há um paralelismo entre a ordem do discurso e a ordem do relato: o discurso declara o término da ida e o inicio da volta. Essa mesma perspectiva propõe o lexema agora em "evitavam agora os es pinhaços", em oposição a $\underline{\underline{a n t e s}}$, ao sublinhar a coincidência entre díf curso e relato: A perspectiva implicita na comparaçao dos pousos da co mitiva é a mesma: "Mas quase as mesmas, que na ida, eram as que procu_ r ava. . . "

Essa perspectiva própria ã estória, e respeitada pela enuncia ção, leva o leitor a esperar na relação das fazendas, duas vezes visi tadas, a ordem do retorno. Ñao é isso, porém, o que acontece: noúltí_ mo instante, o aviso de troca de orientaçao dado pelo tempo verbal:

"... as principais t i nham sido", isto é, na $\underline{\underline{i d a}}$.

Os dois parágrafos seguintes, ao referirem primeiro o orgulho de Pedro orósio ao "ver o alto valor com que seo Alquiste contemplavá o seu país natalício", e, depois, a vacilação de ator entre voltar ou ficar nos Gerais, conduzem o leitor novamente até o fim do trajeto de ida. E logo depois, de chofre, ei-lo no meio da viagem de volta.

Na narração da volta, uma nova oposição quanto ao tratamento dispensado ás fazendas. A narração só se demora nos fatos aconteci dos na fazenda de dona Vininha, isto é, a penúltima do trajeto ainda não terminado. As anteriores quase desaparecem:

são relegadas no discurso a simples locativo, às vezes de ações do ator principal, mas ã primeira vista de pouca monta (as pazes de Ivo e Pedro orósio, pre paradas desde o início da narrativa). A partir de então, o leitor ípa sa a participar dos acontecimentos que ocorrem no espaço compreendido entre as duas últimas fazendas e o arraial do Rosário.

Esses expedientes todos desviam a atenção do leitor para o rela to, não o deixando atentar em certos detalhes. o primeiro deles é a relação que se passa a estabelecer entre os fatos que ocorrem com a comitiva e o lugar onde estes se dão, de um lado, e de outro, o nome $-30-$ 
do proprietário da fazenda.

Vejamos.

A reconciliação definitiva de Ivo e Orósio e a promessa daquele de conseguir o mesmo dos demais companheiros se dão na fazenda de Nho Hermes; a preocupação principal de Pedro orósio ao chegar á Fazenda de dona Vininha é a de encontrar ali moças para namorar; a proprieda de de Jove marca um final agradável da viagem pelas fazendas; i nela que há maior conforto e fartura: "Ali tinha luz elétrica, o povo escu tava rádio, se ia dormirmais tardado. E se comia uma ceia boa".

Vejamos, agora, as observações que o narrador faz acompanhar ca da fazenda ao apresentá-las sumariamente:

a de Jove: entre o Ribeirão Maquiné e o Rio das Pedras (alusão á forma com que Júpiterfoi salvo pela mãe de ser de vorado pelo pai?); fazenda com espaço de casarao e sobrefartura.

a de dona Vininha:"aprazíve1 (...); aí Pedro Orósio principiou - namoro" (mais tarde a fazenda será cognominada também de Boamor) .

a de Nho Hermes: onde acharam notícias do mundo e o seo Jujuca fechou $\stackrel{\text { compr a }}{\underline{\underline{n}}}$ de...

a de Nha Selena: "na ponta da serra de Santa Rita - onde teve festinha e Frei Sinfrão disse duas missas, confessou mais de umas dúzias de pessoas" (seria a manifestação da piedade fraterna da deusa que se suicida ao saber da morte do irmão Hélio?).

a de Marciano: "mediando da cabeceira do Córrego da onça para o Córrego do $\underline{\underline{M e d o}}$, lã o Pedro Orósio quase teve de a ceitar malajuizada briga com um companheiro morrovermelhado": a isotopia bélica se manifesta clara nos termos grifados.

a de Apolinãrio: fazenda limítrofe com os Gerais, na vertente do $\underline{\underline{\text { Formo so }}}$ - ali já eram os campos gerais dentro do $\underline{\underline{\mathrm{sOl}}}$.

Nota-se, a estas alturas, que a escolha dos elementos que indi vidualizam cada fazenda se deve ao narrador, no ato da enunciaçã . Nes sa escolha está evidente a intenção de seccionar o espaço geográfico 
das serras em seis reinos muito bem definidos. Dentro dessa perspecti스 va, entende-se que se no enunciado: "as principais (fazendas) tinham sido", a disjunção feita entre dois grupos do paradigmalfazendas prin c ipa i s / sécundar i a s l pareça numa primeira instância obedecer äo sito de sintetizar a narrativa (evidente no trecho em que esse enunciado se localiza); numa segunda instância, pórem, fica clara a fun ção de proceder-se a uma seleção fundamental no texto; trata-se, nova mente, de distinguir dentre os elementos fornecidos pelo mundo extensional os pertinentes dos não significativos à mensagem narrador-leî tor.

Esta relação motivada entre os nomes dos proprietários e as pre priedades (confirmada por elementos circunstanciais, tais como loca lização geográfica, comportamento de proprietário ou de atores outros) nos obriga a ver uma relação de necessidade também na correspon dincia entre o paradigma geográfico e o dos traidores de pedro or S io.

4.6. Reexaminando, entretanto, o tratamento dispensado pelo rador aos traidores, tanto ao nível do discurso quanto ao do relato, não nos parece ter havido a mesma preocupação de individualizá-los. o único deles que recebe destaque i Ivo, cuja posição de chefe, confir mada várias vezes pelo relato, aparece retratado, como já dissemos, no discurso de Laudelim na expressão: "Eram seis mais um" .

Contrariando o quase anonimato a que na introdução Ivo é reduzi do, em oposiçã̃o marcante a Pedro orósio, o narrrador nos fornece no meio (e só então) da narrativa o apelido que lhe confere maior indivi dualidade. A partir desse momento deixa de ser o ator não-marcado do início para receber marca própria: ele- e Ivo Crônico ou Crônhico. A razão da alcunha é bastante elucidativa: "era um sujeito de muita opi nião, que teimava de cumprir tudo que dava anúncio de um dia de fa zer". A isotopia temporal proposta pelo apelido recebe dos lexemas em pregados na. sua definição várias categorias sêmicas, cuja articulação pode ser resumida dä seguinte forma: realização certa no tempo.

Do ponto de vista da fábula amorosa, verifica-se novamente a re lação motivada entre a alcunha e o referente: Ivo cumpre o seu propó sito de vingança. Entretanto, é preciso atentar para o fato de que o segundo paradigma de deuses tem como denominador comum a categoria disfórica de sua função, o que nos leva ã oposição: 
fazenda-de-d eu ses : euforia : : traidores : disforia.

Essa equação volta a propor a simetria dos dois parad igmas e a pergunta pelo sétimo termo do paradigma dos fazendeiros.

As referências Is fazendas aqui arroladas ocorrem ao narrar-se a volta da comitiva. Reexaminando o trajeto de ida, posto em destaque tanto no discurso quanto no relato pelo episódio de Malaquias, verifí ca-se que este se dã no dia seguinte à passagem da comitiva "na fazen da do Saco-dos-cochos, de seo Juca Saturnino, onde tinha falhado". o ónico fato ali ocorrido mencionado pelo narrador ê: "Aparecera o Me ral, o primo do Ivo, os dois resumiram muita conversa apartada. 0 Må ral, outro que mal escondia o ferrão. Sujeito feioso e lero, focinhudo como o coati". E tudo dito sem maiores preocupações, como a citar de passagem algo que comprove a "meia-bobagem de ciúmes" dos companheiros ("Ainda, na véspera, na Fazenda do Saco-dos-Cochos", diz o narra dor substituindo Pedro Orósio).

Em oposiçã̃o, portanto, às demais fazendas, esta não se encontra entre as "principais" de lista, embora seja a primeira onde per noita o grupo. o destaque em negrito das seis se opoe ainda a fato de que, neste caso, o nome do propriet́ário vem em segundo plano, ocu pando o primeiro o da propriedade. Relacionando tais dados com os se te mensageiros e o trajeto da comitiva, pode-se traçar o seguinte pa ralelo:

i da

\begin{tabular}{c}
\hline mensageiro - Malaquias \\
1 fazendeiro - Saturnino \\
1 traidor $\quad$ v s \\
6 mensageiros \\
6 fazendeiros \\
6 traidores \\
volta
\end{tabular}

A posição de termo marcado da fazenda de Saturnino não se faz, pof tanto, pela oposição destaque/não-destaque dado no discurso. Faz-se pela distribuição pelas duas partes em que se divide a viagem, pois a fazenda de Saturnino se localiza no gráfico ao lado do chefe dos trai dores e do mensageiro fundamental. Essa posição de termo marcado no 
relato se encontra, portanto, diluída no discurso. Ao localiźa-la no início da narrativa, quando o leitor desconhece a trama e intriga da narrativa, a fazenda se perde no meio dos inúmeros aspectos geográficos pitorescos em que abunda esta primeira parte do texto. Por isso, - narrador ao referir-se a ela pode colocar, lado a lado, o nome do proprietário e o da propriedade: Fazenda do Saco-dos-Cochos, de seo Saturnino. Só já quase no final, quando Pedro Órosio pergunta pelos demais companheiros que irão i festa e Ivo responde: "-Estão esperando, no fim do beco do Saturnino", ê que volta o nome do f azende ir o.Ma's ainda desta vez, sem maior destaque. Segue-se a cançao de Laudelim e os dois rapazes se dirigem para o local do baile:

"Aí eis que ali, no Juajim, na última casa sozinha, na saída pa ra o saco-dos-cochos, estavam todos os companheiros, por cerimônia de recongraça" (p. 65).

Além da isotopia eufórica da segunda parte do enunciado ("todos òs companheiros", "cerimônia de recongraça"), o nome da fazenda substitui ã do proprietário, e vem cercado de pormenores ("no Juajém, na última casinha sozinha") que desviam a ateņ̧̃ao do elemento fundamen tal. Identificando-se, porém, o local como o saco-dos-cochos, de pre priedade de Juca Saturnino, identifica-se o sétimo fazendeiro-deus: a Ivo Crônhico corresponde Juca Saturnino.

Vejamos o que ocorre no reino de Saturnino: na ida, o encontro de Ivo com o primo Maral (simples intermediário) os quais, agora sabe mos, tramam a vingança; na volta, é ali que se dá a tentativa de homi cídio: fecha-se o círculo e cumpre-se a função da alcunha de Ivo.

4.7. Completada a relaçao termo a termo entre os dois parąic mas, diferenciados entre si pela distribuição categóricas euforia/dis foria, resta-nos alinhavar a leitura que esses dados propõem.

Tanto no paralelismo com a cañçao de Laudelim como pelos pró prios nomes, os traidores são caracterizados como reis. As propriedades atravessadas pela comitiva constituem reinos individuais. Após o canto de Laudelim, Pedro orósio volta a percorrê-las de memória, iden tifica-se rei de todas aquelas paragens agrestes onde mora:

"toda aquela serra subida (...) cheia de tratos onde ninguém po de pisar e o gavião-grande é dono" (p. 68).

Iguala-se, portanto, a Ivo mas opõe-se a ele pois enquanto o $-34-$ 
seu nome evoca pedra, o imutável, duas vezes, o de Ivo evoca tempo, o mutável. São dois atores, assim caracterizados, que se defrontam na propriedade de Saturnino. A relação Ivo Crônico/pedro orósio e Satur nino pode ser vista, a partir de então, como uma relação hiperonímica de Saturnino que se biparte em crônico e orósio. Istó e uma relação do todo com as partes. A luta sefaz, assim, dentro da unidade.

Remontando, agora, ao saber que a referência mitológica dos no mes. Saturno e cronos nos obriga, é possível identificar em Ivo a Cro nos, o deus devorador de seus filhos, e em Pedro orósio a saturno ro mano, o deus da agricultura. Não por acaso pedro orósio é agricultor. Conta o mito que saturno, destronado pelo filho, veio para o Lácio on de promove à idade de ouro através da agricultura. Lácio, o nome do

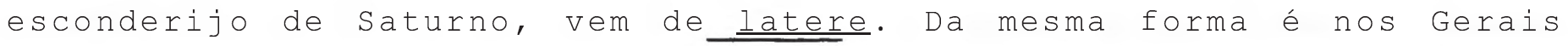
que se esconde Pedro Orósio, temeroso do crime que possa ter cometi do. Uma vez de posse de seu destino, é ali onde deverá promover a a gricultura com que reparará a carência da região, situaçao inicial desta narrativa.

NOTAS

(1) Edição citada neste trabalho: NO URUBUQUAQŨ̃, NO PINHÊM. $3 a$. ed. ("Corpo de Baile"), Rio, José'olympio, 1965.

(2) Lotman e Pjatigorki - "Le texte et la fonction". Semiót ica 1-2, $1969, \mathrm{p} \cdot 106$

(3) id.ib. p. 212 .

(4) Veja-se como analisa o Professor Prado Jr. a figura do morro da Garça: "Lá, lã fora lá está o morro. Escaleno, ele é triangular, fino em sua forma e nítido em seu perfil, mas ele é escuro, espes so, e pesado. Forma natural, une a regularidade da figura geomé trica, o espaço claro, ã densidade e -a escuridão das coisas mate riais. Participa, ao me smo tempo, do universo transparente do pen sar, da inteligência, e da opacidade das coisas dadas e encontra das, brutas e pré-humanas. Como as coisas do homem, como os símbo los que ele produz, o morro fala e tem sentido; como as coias da natureza, ele é e transcende o falar humano. Essa estranha união nos faz pensar nos artefacta: pois é no objeto técnico, que se 
opera esse casamento entre a matéria e a forma, entre a resistên cia da inércia e a teleologia. $\underline{0 \text { morro é uma pirâmide }}$, objeto am bìguo, o morro nos remete a outro objeto ambíguo. Pois a pirâmide é mais que um objeto técnico, é mais que um edifício ou que uma sepultura. Limiar entre a vida e a morte, a pirâmide i mais passa gem que nos conduz do humano àquilo que o transcende, ultrapassa toda técnica, pois é essencialmente traves s ia. Ela participa da mesma natureza da esfinge e, na promiscuidade entre pirâmide e es finge, abre o espaço que torna possível o comércio entre o homem e os deuses, que possuem o segredo do destino. É por isso que a esfinge, enigma e desafio, é a fonte de uma linguagem cifrada, men sagem absoluta, proposta à perplexidade do sujeito empírico e con tingente". ("0 Destino cifrado - linguagem e existência em Guimarã̃es - CavaloAzul, 3, p.23).

(5) A profissã̃o de agricultor implica também a oposição sedentário/ nômade, como deixa claro o trecho: "Não imaginava como era que al guém podia querer ser trabalhador de trem de ferro, guarda-freio, foguista, maquinista" (...) "Viajar era bom, mas por curto prazo de tempo", (p. 57).

(6) Greimas, "La structure des actants du récit". In Du $\underline{\underline{\text { sens }}}$ Paris, Seuil, 1970, p. 258 . 